\title{
Analysis of consumption of omega 3 source foods by participants of social groups
}

Fhaira Petter da Silva Stefanello' $\mathbb{( D}$ Adriano Pasqualotti ${ }^{2}$ ID Nadir Antonio Pichler ${ }^{3} \mathbb{I D}$

\section{Abstract}

Objective: To verify the consumption of omega 3 source foods by participants of social groups. Method: a cross-sectional, descriptive analytical study was carried out with 850 older participants of social groups of the Older Adult Care Coordination (or DATI) in a city in the state of Rio Grande do Sul, Brazil, through a questionnaire containing sociodemographic variables and the consumption of omega 3 source foods. Data were analyzed using the R 2.15.1 language and using the Chi-square and Fisher's exact tests. The level of significance used in the tests was $p \leq 0.05$. Results: The results showed that older women have a habit of consuming more omega 3 source foods than men, such as oils, dark green vegetables, seeds, fish and nuts, and people with greater purchasing power consume more products with omega 3. Conclusion: Families with greater purchasing power used more expensive sources of omega 3 fatty acid, and the consumption of these products did not differ significantly in terms of age, BMI, marital status and whether the individual lived alone or with others.

\footnotetext{
Universidade de Passo Fundo (UPF), Programa de Pós-graduação em Envelhecimento Humano, da Universidade de Passo Fundo (UPF). Palmeira das Missões, RS, Brasil.

2 Universidade de Passo Fundo (UPF), Departamento de Estatística e Matemática, Programa de Pós-graduação em Envelhecimento Humano, da Universidade de Passo Fundo (UPF). Passo Fundo, RS, Brasil.

3 Universidade de Passo Fundo (UPF), Departamento de Filosofia, Programa de Pós-graduação em Envelhecimento Humano, da Universidade de Passo Fundo (UPF). Passo Fundo, RS, Brasil.
}

\section{Keyword: Nutrition.} Health of the Elderly. Fatty Acids Omega-3. Food Consumption.

The authors declare there are no conflicts of interest in relation to the present study.

No funding was received in relation to the present study.

Correspondence 


\section{INTRODUCTION}

With the advances in medicine, technology and lifestyle of recent decades, life expectancy has increased significantly ${ }^{1}$. According to the Brazilian Institute of Geography and Statistics ${ }^{2}$, there are 30.2 million people aged over 60 in Brazil, causing a significant change in the country's age pyramid.

Aging is a natural process of human life. Over time, physiological, physical, psychological, brain and social changes occur as a result of this process ${ }^{3,4}$. However, healthy habits developed throughout life, such as the practicing of physical activity, a healthy lifestyle, autonomy and suitable food choices play a fundamental role in quality of life ${ }^{5}$.

Dietary patterns are one of the main determinants of health. The beneficial effects of eating foods with protective functions are well known, and include a reduction in the risk of mortality ${ }^{4}$. The consumption of omega 3 fatty acids is associated with numerous health benefits ${ }^{1,5}$, such as the improvement of the metabolic syndrome, the reduction of abdominal obesity, insulin resistance, dyslipidemia and hypertension. There is also a reduced risk of cardiovascular disease, symptoms of depression, weight, postprandial satiety and inflammatory diseases $^{6-10}$.

The fatty acids of the omega 3 series, formed by linolenic acid, docosahexaenoic acid (DHA), eicosapentaenoic acid (EPA) and docosapentaenoic acid (DPA), constitute a group of lipids that exercise significant functions in the body, being incorporated into the phospholipids of the membranes of the cells and optimizing their biological function. This optimization particularly occurs in the structure and function of the glia and endothelium brain cells, strengthening memory and neuroinflammatory control, as well as in the retina, testicles, heart, liver and kidneys ${ }^{4,11-14}$. Various benefits have been reported from the ingestion of omega 3 , such as the reduction of inflammatory eicosanoids, cytokines and reactive oxygen species, preventing and treating cardiovascular diseases, inflammatory diseases and infections and reducing the occurrence of injuries, immunological changes and acting in the reduction of cognitive decline $e^{7,8}$.
With the aging process, there is the possibility of the appearance of cardiac, endocrine and dementia pathologies and the development of inflammation and oxidative stress ${ }^{8}$. The use of omega 3 supplementation can lead to reductions in oxidative stress, a decline in the expression of pro-inflammatory proteins and an increase in the expression of anti-inflammatory proteins, as well as improvement in the cognitive decline associated with pathologies, classified as mild to moderate ${ }^{8-10}$.

An integrative literature review study ${ }^{15}$, with the objective of identifying the use of omega 3 supplementation and its performance in cognitive development in older adults, found a reasonable improvement in cognitive performance, memory and cerebrovascular and arterial function, while also pointing out that further studies are still required.

There is a lack of data in Brazilian ${ }^{15}$ and international ${ }^{16,17}$ literature on the food-based consumption of omega 3 and its benefits among participants of social groups. Early diagnosis to identify the absence of these acids is intended to prevent disease and improve quality of life. Thus, the objective of the present study was to assess the consumption of omega 3 source foods by participants of social groups.

\section{METHOD}

A cross-sectional, descriptive/analytical and population based study was carried out in 2016, with 850 older adults participating in social groups of the Elderly Care Coordination (or DATI) in a city in the state of Rio Grande do Sul. The sample size $(\mathrm{n}=850)$ was defined for a finite population of 3,600 older adults and with a 95\% confidence interval, based on a sampling error of $3 \%$. The convenience sampling technique was used. The selection of participants was based on their availability to undertake activities in the DATI workshops.

The inclusion criteria were: participants linked to DATI social groups, while people with beta blockers, pacemakers or autoimmune diseases were excluded.

Before signing the Informed Consent Term (ICF), the researchers explained the objectives of the 
research and how the instrument should be completed. Afterwards, the participants signed the informed consent form and completed the questionnaire, in the classroom and during workshop activities at the DATI, which included dance, music, yoga and reading, etc. and lasted 15 minutes. The instrument consisted of sociodemographic variables (age, sex, education, marital status, risk factors such as muscle pain, medication use, bone disorders); questions about omega 3 supplementation in capsules and the consumption of omega 3 source foods, with a table with the source food and frequency of consumption: never, weekly, biweekly, monthly and yearly (animal and vegetable sources of omega 3 foods, such as DHA, EPA and ALA); soy oil and other oils (olive oil, canola and corn oil); vegetables (broccoli, cabbages and spinach); fish (sardines, salmon, tuna and cod); seeds (such as chia and flaxseed) and nuts, as well as the measurement of body mass index $(\mathrm{BMI})^{18,19}$.

The data were analyzed using the R 2.15.1 language. Pearson's Chi-square and Fisher's exact tests were applied. The level of significance used in the tests was $p \leq 0.05$. The study was approved by the Ethics Committee of the Universidade de Passo Fundo (Passo Fundo University) (UPF), under opinion no. 1,023,088.

\section{RESULTS}

Of the 850 older participants, 739 (86.9\%) were women and $111(14 \%)$ were men. The mean age was $67.9 \pm 8.0$ years; in terms of education, 339 (42.1\%) had up to 4 years of schooling, 367 (45.6\%) from 5 to 10 years and $99(12.3 \%) 11$ years or more. In relation to income, $586(71.9 \%)$ received up to $\mathrm{R} \$ 1,575.99$; with regard to marital status, $62(7.3 \%)$ were single, 338 (39.8\%) were married, 100 (11.8\%) were separated or divorced, and $348(40.9 \%)$ were widowed. A total of $524(63.0 \%)$ of the older adults lived with someone.

Table 1 shows the results of the association between the sex of the sample studied $(n=850)$ and the consumption of omega 3 source foods.

The results in Table 1 indicate a significant difference in relation to the consumption of seeds between the sexes, with women consuming more seeds than men $(p=0.001)$.

Table 2 shows the results of the relationship between the age group of the sample studied $(\mathrm{n}=$ $850)$ and the consumption of omega 3 source foods.

Table 1. Association between the sex of the sample $(n=850)$ and the consumption of omega 3 source foods.

\begin{tabular}{|c|c|c|c|c|}
\hline \multirow{2}{*}{ Omega 3 source foods } & & \multicolumn{2}{|c|}{ Sex } & \multirow{2}{*}{$p$} \\
\hline & & Female & Male & \\
\hline \multirow[t]{2}{*}{ Soy oil } & Yes & $560(85.6 \%)$ & $83(84.7 \%)$ & 0,760 \\
\hline & No & $94(14.4 \%)$ & $15(15.3 \%)$ & \\
\hline \multirow[t]{2}{*}{ Other oils } & Yes & $269(45.1 \%)$ & $35(37.6 \%$ & 0,217 \\
\hline & No & $328(54.9 \%)$ & $58(62.4 \%)$ & \\
\hline \multirow[t]{2}{*}{ Dark green vegetables (broccoli, kale and spinach) } & Yes & $652(95.6 \%)$ & $96(93.2 \%)$ & 0,314 \\
\hline & No & $30(4.4 \%)$ & $7(6.8 \%)$ & \\
\hline \multirow[t]{2}{*}{ Fish } & Yes & $521(78.3 \%)$ & $81(80.2 \%)$ & 0,795 \\
\hline & No & $144(21.7 \%)$ & $20(19.8 \%)$ & \\
\hline \multirow[t]{2}{*}{ Seeds (chia and flaxseed) } & Yes & $372(58.7 \%)$ & $32(34.8 \%)$ & 0,001 \\
\hline & No & $262(41.3 \%)$ & $60(65.2 \%)$ & \\
\hline \multirow[t]{2}{*}{ Nuts } & Yes & $431(69.1 \%)$ & $63(67.0 \%)$ & 0,721 \\
\hline & No & $193(30.9 \%)$ & $31(33.0 \%)$ & \\
\hline
\end{tabular}

Fisher's Exact Test; Significant value $=p \leq 0.05$. 
Table 2. Association between the age group of the sample studied $(n=850)$ and the consumption of omega 3 source foods.

\begin{tabular}{|c|c|c|c|c|c|}
\hline \multirow{2}{*}{ Omega 3 source foods } & & \multicolumn{3}{|c|}{ Age range } & \\
\hline & & From 50 to 59 years & From 60 to 79 years & 80 years or over & \\
\hline \multirow[t]{2}{*}{ Soy oil } & Yes & $101(92.7 \%)$ & $491(83.9 \%)$ & $51(87.9 \%)$ & \multirow[t]{2}{*}{0.051} \\
\hline & No & $8(7.3 \%)$ & $94(16.1 \%)$ & $7(12.1 \%)$ & \\
\hline \multirow[t]{2}{*}{ Other oils } & Yes & $42(40.8 \%)$ & $234(43.6 \%)$ & $28(56.0 \%)$ & \multirow[t]{2}{*}{0.183} \\
\hline & No & $61(59.2 \%)$ & $303(56.4 \%)$ & $22(44.0 \%)$ & \\
\hline \multirow{2}{*}{$\begin{array}{l}\text { Dark green vegetables } \\
\text { (broccoli, kale and spinach) }\end{array}$} & Yes & $110(94.8 \%)$ & $584(95.6 \%)$ & $54(93.1 \%)$ & \multirow[t]{2}{*}{0.674} \\
\hline & No & $6(5.2 \%)$ & $27(4.4 \%)$ & $4(6.9 \%)$ & \\
\hline \multirow[t]{2}{*}{ Fish } & Yes & $84(73.7 \%)$ & $472(79.2 \%)$ & $46(82.1 \%)$ & \multirow[t]{2}{*}{0.336} \\
\hline & No & $30(26.3 \%)$ & $124(20.8 \%)$ & $10(17.9 \%)$ & \\
\hline \multirow[t]{2}{*}{ Seeds (chia and flaxseed) } & Yes & $64(60.4 \%)$ & $314(55.5 \%)$ & $26(48.1 \%)$ & \multirow[t]{2}{*}{0.333} \\
\hline & No & $42(39.6 \%)$ & $252(44.5 \%)$ & $28(51.9 \%)$ & \\
\hline \multirow[t]{2}{*}{ Nuts } & Yes & $73(67.6 \%)$ & $387(69.5 \%)$ & $34(64.2 \%)$ & \multirow[t]{2}{*}{0.695} \\
\hline & No & $35(32.4 \%)$ & $170(30.5 \%)$ & $19(35.8 \%)$ & \\
\hline
\end{tabular}

Pearson's Chi-square test; Significant value $=p \leq 0.05$.

The results of Table 2 do not indicate significant differences for consumption of omega 3 source foods, when compared with the age group.

Table 3 shows the results of the relationship between the income of the sample studied $(\mathrm{n}=850)$ and consumption of omega 3 source foods.

The results in Table 3 indicate a significant difference in relation to the consumption of fish ( $p=0.014)$ and nuts $(p=0.004)$ based on income, showing that people who have an income greater than or equal to $R \$ 1,576.00$ tend to consume more omega 3 source foods.
Table 4 shows the results of the relationship between the marital status of the studied sample $(n=850)$ and the consumption of omega 3 source foods.

The results of Table 4 do not indicate significant differences in the consumption of Omega 3 source foods based on marital status.

Table 5 presents the results of the relationship between the Body Mass Index (BMI) of the studied sample $(n=850)$ and the consumption of omega 3 source foods. 
Table 3. Association between the income of the sample studied $(n=850)$ and the consumption of omega 3 source foods.

\begin{tabular}{|c|c|c|c|c|}
\hline \multirow{2}{*}{ Omega 3 source foods } & & \multicolumn{2}{|c|}{ Income } & \multirow{2}{*}{$p$} \\
\hline & & Up to $\mathrm{R} \$ 1,575.99$ & $\mathrm{R} \$ 1,576.00$ or more & \\
\hline \multirow[t]{2}{*}{ Soy oil } & Yes & $441(85.5 \%)$ & $174(84.9 \%)$ & \multirow[t]{2}{*}{0.817} \\
\hline & No & $75(14.5 \%)$ & $31(15.1 \%)$ & \\
\hline \multirow[t]{2}{*}{ Other oils } & Yes & $199(42.5 \%)$ & $96(49.5 \%)$ & \multirow[t]{2}{*}{0.104} \\
\hline & No & $269(57.5 \%)$ & $98(50.5 \%)$ & \\
\hline \multirow{2}{*}{$\begin{array}{l}\text { Dark green vegetables } \\
\text { (broccoli, kale and spinach) }\end{array}$} & Yes & $505(94.7 \%)$ & $214(97.7)$ & \multirow[t]{2}{*}{0.79} \\
\hline & No & $28(5.3 \%)$ & $5(2.3 \%)$ & \\
\hline \multirow[t]{2}{*}{ Fish } & Yes & $393(76.2 \%)$ & $184(84.4 \%)$ & \multirow[t]{2}{*}{0.014} \\
\hline & No & $123(23.8 \%)$ & $34(15.6 \%)$ & \\
\hline \multirow[t]{2}{*}{ Seeds (chia and flaxseed) } & Yes & $268(54.8 \%)$ & $120(58.0 \%)$ & \multirow[t]{2}{*}{0.454} \\
\hline & No & $221(45.2 \%)$ & $87(42.0 \%)$ & \\
\hline \multirow[t]{2}{*}{ Nuts } & Yes & $322(66.1 \%)$ & $157(77.3 \%)$ & \multirow[t]{2}{*}{0.004} \\
\hline & No & $165(33.9 \%)$ & $46(22.7 \%)$ & \\
\hline
\end{tabular}

Fisher's exact test; Significant value $=p \leq 0.05$.

Table 4. Association between the marital status of the studied sample $(n=850)$ and the consumption of omega 3 source foods.

\begin{tabular}{|c|c|c|c|c|c|c|}
\hline \multirow{2}{*}{ Omega 3 source foods } & & \multicolumn{4}{|c|}{ Marital status } & \multirow[b]{2}{*}{$p$} \\
\hline & & Single & Married & $\begin{array}{l}\text { Separated/ } \\
\text { Divorced }\end{array}$ & Widowed & \\
\hline \multirow[t]{2}{*}{ Soy oil } & Yes & $48(90.6 \%)$ & $255(85.9 \%)$ & $78(82.1 \%)$ & $261(85.3 \%)$ & \multirow[t]{2}{*}{0.568} \\
\hline & No & $5(9.4 \%)$ & $42(14.1 \%)$ & $17(17.9 \%)$ & $45(14.7 \%)$ & \\
\hline \multirow[t]{2}{*}{ Other oils } & Yes & $14(32.6 \%)$ & $123(43.6 \%)$ & $38(44.7 \%)$ & $129(46.1 \%)$ & \multirow[t]{2}{*}{0.423} \\
\hline & No & $29(67.4 \%)$ & $159(56.4 \%)$ & $47(55.3 \%)$ & $151\left(53.9^{\circ} \%\right)$ & \\
\hline \multirow{2}{*}{$\begin{array}{l}\text { Dark green vegetables } \\
\text { (broccoli, kale and spinach) }\end{array}$} & Yes & $52(94.5 \%)$ & $304(95.6 \%)$ & $90(94.7 \%)$ & $300(95.5 \%)$ & \multirow[t]{2}{*}{0.978} \\
\hline & No & $3(5.5 \%)$ & $14(4.4 \%)$ & $5(5.3 \%)$ & $15(4.8 \%)$ & \\
\hline \multirow[t]{2}{*}{ Fish } & Yes & $40(76.9 \%)$ & $242(78.1 \%)$ & $74(80.4 \%)$ & $244(78.7 \%)$ & \multirow[t]{2}{*}{0.956} \\
\hline & No & $12(23.1 \%)$ & $68(21.9 \%)$ & $18(19.6 \%)$ & $66(21.3 \%)$ & \\
\hline \multirow[t]{2}{*}{ Seeds (chia and flaxseed) } & Yes & $22(48.9 \%)$ & $172\left(57.9^{\circ} \%\right)$ & $52(59.8 \%)$ & $157(53.0 \%)$ & \multirow[t]{2}{*}{0.413} \\
\hline & No & $23(51.1 \%)$ & $125(42.1 \%)$ & $35(40.2 \%)$ & $139(47.0 \%)$ & \\
\hline \multirow[t]{2}{*}{ Nuts } & Yes & $33(64.7 \%)$ & $212(72.4 \%)$ & $56(65.1 \%)$ & $191(66.8 \%)$ & \multirow[t]{2}{*}{0.362} \\
\hline & No & $18(35.3 \%)$ & $81(27.6 \%)$ & $30(34.9 \%)$ & $95(33.2 \%)$ & \\
\hline
\end{tabular}

Pearson's Chi-square test; Significant value $=p \leq 0.05$. 
Table 5. Association between Body Mass Index (BMI) of the sample studied $(n=850)$ and the consumption of omega 3 source foods.

\begin{tabular}{|c|c|c|c|c|c|}
\hline \multirow{2}{*}{ Omega 3 source foods } & & \multicolumn{3}{|c|}{ Body Mass Index (BMI) } & \\
\hline & & Malnutrition & Normal Weight & Obesity & \\
\hline \multirow[t]{2}{*}{ Soy oil } & Yes & $53(84.1 \%)$ & $266(82.6 \%)$ & $324(88.3 \%)$ & \multirow[t]{2}{*}{0.102} \\
\hline & No & $10(15.9 \%)$ & $56(17.4 \%)$ & $43(11.7 \%)$ & \\
\hline \multirow[t]{2}{*}{ Other oils } & Yes & $28(46.7 \%)$ & $132(44.3 \%)$ & $144(43.4 \%)$ & \multirow[t]{2}{*}{0.889} \\
\hline & No & $32(53.3 \%)$ & $166(55.7 \%)$ & $188(56.6 \%)$ & \\
\hline \multirow{2}{*}{$\begin{array}{l}\text { Dark green vegetables } \\
\text { (broccoli. kale and spinach) }\end{array}$} & Yes & $66(97.1 \%)$ & $321(95.0 \%)$ & $361(95.3 \%)$ & \multirow[t]{2}{*}{0.759} \\
\hline & No & $2(2.9 \%)$ & $17(5.0 \%)$ & $18(4.7 \%)$ & \\
\hline \multirow[t]{2}{*}{ Fish } & Yes & $51(76.1 \%)$ & $253(76.7 \%)$ & $298(80.8 \%)$ & \multirow[t]{2}{*}{0.398} \\
\hline & No & $16(23.9 \%)$ & $77(23.3 \%)$ & $71(19.2 \%)$ & \\
\hline \multirow[t]{2}{*}{ Seeds (chia and flaxseed) } & Yes & $34(55.7 \%)$ & $166(54.4 \%)$ & $204(56.7 \%)$ & \multirow[t]{2}{*}{0.845} \\
\hline & No & $27(44.3 \%)$ & $139(45.6 \%)$ & $156(43.3 \%)$ & \\
\hline \multirow[t]{2}{*}{ Nuts } & Yes & $40(65.6 \%)$ & $213(69.4 \%)$ & $241(68.9 \%)$ & \multirow[t]{2}{*}{0.842} \\
\hline & No & $21(34.4 \%)$ & $94(30.6 \%)$ & $109(31.3 \%)$ & \\
\hline
\end{tabular}

Pearson's Chi-square test; Significant value $=p \leq 0.05$.

The results of Table 5 do not indicate a significant difference in the consumption of Omega 3 source foods based on Body Mass Index (BMI).

\section{DISCUSSION}

Omega 3 fatty acids are associated with preventing or reducing the severity of a multitude of diseases, from metabolic diseases such as heart disease, diabetes and kidney disease, neurodegenerative diseases, such as Alzheimer's disease, and inflammatory diseases, including osteoarthritis. Omega 3 acts by attenuating the development of atherosclerosis or arterial plaques, reducing concentrations of inflammation-signaling molecules ${ }^{1,5}$.

Western diets, due to the disproportionate and high consumption of saturated fatty acids among a large part of the population, derived from foods of animal origin, contain fewer omega 3 fatty acids, a factor that increases the risk of type 2 diabetes and cardiovascular diseases ${ }^{7,20,21}$. Omega 3 fatty acids are found in greater quantities in the diet of the Mediterranean population, including older adults, as they are found in natural foods, such as nuts, flax seeds, chia and salmon.
Table 1 of the present study shows that men consume fewer seeds than women, possibly influenced by different eating habits. Consequently, it is women who have healthier diets, because, in most cases, they have the responsibility of taking care of their family's diet, whether buying, choosing or preparing food ${ }^{22}$, thereby consuming more seeds, such as those that are sources of omega 3 , identified in this study, which bring more health benefits. For this reason, in addition to caring more for their health and carrying out periodic examinations more frequently, women aspire to a greater life expectancy ${ }^{23}$ and generally participate more in social groups $^{24}$.

Flaxseed is a seed rich in omega 3 and has been studied for its benefits in reducing the risk of chronic diseases and its antioxidant, anticancer and hyperglycemic agents, and also due to its effect on estrogen levels, blocking the enzymes active in hormonal metabolism, in order to interfere with the growth of tumor cells ${ }^{25}$. Flaxseed is the most abundant plant source of omega 3 and has been associated with health, the prevention and treatment of heart disease, arthritis, inflammatory and autoimmune diseases and cancer ${ }^{25}$. 
The data in Table 2 shows that there were no significant differences in the consumption of Omega 3 source foods based on age group. However, the results, according to Table 3 , reveal that there is a significant difference in the consumption of fish $(p=0.014)$ and nuts $(p=0.004)$ by income, demonstrating the participants with income greater than or equal to $\mathrm{R} \$ 1,576.00$ consume more Omega 3 source foods.

According to Borges et al. ${ }^{26}$, the consumption of food by Brazilian families is influenced by income and prices. This was confirmed by the record of food purchases provided by the Family Budget Survey (POF 2008/2009), which identified that the health status of individuals is directly related to the inadequate quality of their diet and is directly influenced by social class, as the results found that the quality of health of people belonging to the highest social class is superior to that of the lower classes.

The study by Coelho, Aguiar and Fernandes ${ }^{27}$ assessed the impossibility of the lower social class of the population maintaining an adequate diet, following national proposals, such as the Food Guide for the Brazilian Population. Low-income families purchase less healthy foods, such as whole grains, skimmed milk and by-products, lean meats, fruits, vegetables, fish and nuts.

Fish and nuts contain notable amounts of omega 3 fatty acids and can provide a preventive action against the incidence of many diseases, including cardiovascular illnesses ${ }^{28}$. The American Heart Association suggests the consumption of $226.8 \mathrm{~g}$ of fish twice a week ${ }^{29}$. The study by Rohrmann and $\mathrm{Faeh}^{28}$ found that people who eat nuts more than three times a week can prevent premature deaths from cardiovascular disease and cancer in comparison with non-consumers.

The study by Darmon et al. ${ }^{30}$, the objective of which was to explore the relationship between income and healthy eating and the impact of healthy food pricing policies on the expenditure on and nutritional quality of foods chosen by low- and middle-income women, showed that the amount of unhealthy products purchased by the low-income group was twice that of those purchased by women in the middle-income group. As such, low-income women had diets of low nutritional quality, compared to middle-income women who purchased food products with protective characteristics to the body, generating more health among their families.

As such, the regular consumption of omega 3 fatty acids contributes to a healthier diet and better quality of life, protecting older adults from cardiovascular, inflammatory and chronic diseases, fighting cancer, obesity and improving bone health, as it strengthens the brain metabolism ${ }^{28,30}$.

The limitations of the present study revolve around the need to undertake more detailed analyzes to expand the discussion, verifying the relationships between the consumption of Omega 3 source foods and the socio-demographic and nutritional profile of older adults participating in other social groups, showing that the consumption of these source foods generates a healthier nutritional status.

\section{CONCLUSION}

In accordance with the purpose of the study, the results showed that older women consume more Omega 3 source foods than men. One of the justifications for this is that, culturally, women were responsible for taking care of their family's food and, consequently, became aware of the importance of consuming healthier products, such as oils, dark green vegetables, seeds, fish and nuts. Regular consumption of these products, which are rich in omega 3, generates a better quality of life for the general population and especially for older adults. In addition, it was found that people with greater purchasing power consume more expensive sources of omega 3 fatty acid and that the consumption of Omega 3 source foods did not differ significantly in relation to age, BMI, marital status and whether the individual lived alone or with others.

Edited by: Ana Carolina Lima Cavaletti 


\section{REFERENCES}

1. Shi Z, Zhang T, Byles J, Martin S, Avery JC, Taylor AW. Food habits, lifestyle factors and mortality among oldest old chinese: the Chinese Longitudinal Healthy Longevity Survey (CLHLS). Nutrients. 2015;7(9):7562-79.

2. Instituto Brasileiro de Geografia e Estatística. Senso da população brasileira de 2017. Brasília, DF:IBGE; 2017.

3. Nordon DG, Guimarães RR, Kozonoe DY, Mancilha VS, Dias Neto VS. Perda cognitiva em idosos. Rev Fac Ciênc Méd Sorocaba. 2009;11(3):5-8.

4. Saavedra LPJ, Silva BFA, Moreira VM, Carvalho IZ. Estado nutricional e consumo alimentar de ácidos graxos eicosapentaenóico e docosahexaenóico associados à função cognitiva em idosos. Uningá Rev. 2016;28(2):40-6.

5. Vidmar MF, Siqueira LO, Brito VB, Martins CAQ, Pimentel GL, Almeida CR, et al. Suplementação com ômega-3 pós-reconstrução do ligamento cruzado anterior. Rev Bras Med Esporte. 2016;22(2):131-7.

6. Brito JVR, Jesus FM, Beserra JF, Eduardo AMLN. Suplementação de Ômega-3 em praticante de exercício físico intenso. REVISA. 2019;8(2):215-27.

7. Maggi C. Câncer $360^{\circ}$ : orientações para uma vida melhor, orientações nutricionais: pacientes, familiares e cuidadores. Recife: Editora Carpe Diem; 2018.

8. Scragg R, Stewart AW, Waayer D, Lawes CMM, Toop L, Sluyter J, et al. Effect of monthly high-dose vitamin D supplementation on cardiovascular disease in the vitamin D assessment study: a randomized clinical trial. JAMA Cardiol. 2017;2(6):608-16.

9. Anacleto GMC, Rica RL, Maifrino LBM, Maia AF, Ribeiro SML, Bocalini DS, et al. Additional effects of stretching training program and supplementation with ômega-3 in older people. J Phys Educ Sport. 2019;19(Suppl 2):473-80.

10. Kaur M, Basu S, Shivhare S. Omega-3 fatty acids: nutritional aspects, sources, and encapsulation strategies for food fortification. Dir Res J Health Pharmacol. 2015;3(1):12-31.

11. Hashimoto K. Role of soluble epoxide hydrolase in metabolism of Pufas in psychiatric and neurological disorders. Front Pharmacol. 2019;10(1):36-40.

12. Namara RK, Asch RH, Lindquist DM, Krikorian R. Role of polyunsaturated fatty acids in human brain structure and function across the lifespan: an update on neuroimaging findings. Prostaglandins Leukot Essent Fatty Acids. 2018;136(1):23-34.
13. Layé S, Nadjar A, Joffre C, Bazinet RP. Antiinflammatory effects of omega-3 fatty acids in the brain: physiological mechanisms and relevance to pharmacology. Pharmacol Rev. 2018;70(1):12-38.

14. Thompson FE, Subar AF. Dietary Assessment Methodology. In: Coulston AM, Boushey GH. Nutrition in the prevention and treatment of disease. $2^{\text {nd }}$ ed. San Diego: Academic Press; 2017. p. 5-44.

15. Oliveira FP, Lima GC, Alves JC, Rodrigues Ml. Suplementação com ômega-3 e desempenho cognitivo de idosos: uma revisão da literatura. Anais do Congresso Nacional Universidade, EAD e Software Livre. 2018.

16. Howe PRC, Evans HM, Kuszewski JC, Wong RHX. Effects of long chain Omega-3 Polyunsaturated Fatty Acids on Brain function in mildly hypertensive older adults. Nutrients. 2018;10(1413):1-14.

17. Baleztena J, Ruiz-Canela M, Pardo M, Sayon-Orea C. Association between cognitive function and supplementation with omega-3 PUFAs and other nutrients in $>75$ years old patients: a randomized multicenter study. Plos ONE. 2018;3(3):1-15.

18. Steluti J. Consumo alimentar: guia para avaliação. Barueri, SP: Manole; 2019.

19. Malta M, Cardoso LO, Bastos FI, Magnanini MF, Silva CFP. Iniciativa STROBE: subsídios para a comunicação de estudos observacionais. Rev Saúde Pública. 2010;44(3):559-65.

20. Guasch-Ferré M, Estruch R, Becerra-Tomás N, Ruiz-Canela M, Corella D, Schröder H, et al. Total and subtypes of dietary fat intake and risk of type 2 diabetes mellitus in the Prevención con Dieta Mediterránea (PREDIMED) study. Am J Clin Nutr. 2017;105(3):723-35.

21. Lewis JD, Abreu MT. Diet as a trigger or therapy for inflammatory bowel Diseases. Gastroenterology. 2017;152(2):398-414.

22. Bernardes AFM, Silva CG, Frutuoso MFP. Healthy eating, health care and gender: perceptions of men and women from the Northwest region of Santos-SP. Demetra. 2016;11(3):559-73.

23. Giora FC, Costa NDC, Marandola ME. Woman's economic participation in the labour Market. Rev Eletrôni Ciênc Empres. 2017;9(13):33-42.

24. Tavares EL, Santos DM, Ferreira A A, Menezes MFG. Nutritional assessment for the elderly: modern challenges. Rev Bras Geriatr Gerontol. 2015;18(3):643-50. 
25. Saini RK, Keum YK. Omega-3 and omega-6 polyunsaturated fatty acids: Dietary sources, metabolism, and significance: a review. Life Sci. 2018;203:255-67.

26. Borges CA, Claro RM, Martins AP, Villar BS. Quanto custa para as famílias de baixa renda obterem uma dieta saudável no Brasil? Cad Saúde Pública. 2015;31(1):137-48.

27. Coelho AB, Aguiar DRD, Fernandes EA. Padrão de consumo de alimentos no Brasil. Rev Econ Sociol Rural. 2009;47:335-62.
28. Rohrmann S, Faeh D. Should we go nuts about nuts? BMC Med. 2013;11(1):165-74.

29. Little MO, Morley JE. Considerando a medicina complementar e a alternativa para idosos. In: Williams BA, Chang A, A halt C, Chen H, Conant RC, Landefeld S, et al, Org. CURRENT: Geriatria: Diagnóstico e tratamento. Tradução André Garcia Islabão, Jussara Burnier e Renate Müller. Porto Alegre: AMGH; 2015. p. 557-658.

30. Darmon N, Lacroix A, Muller L, Ruffieux B. Food price policies improve diet quality while increasing socioeconomic inequalities in nutrition. Int J Behav Nutr Phys Act. 2014;11(66):1-12. 